\title{
INTERPRETASI KONDISIAIR BAWAH TANAH STUDI KASUS DI KECAMATAN TENAYAN RAYA KOTA PEKANBARU DENGAN MENGGUNAKAN METODE PUMPING TEST
}

\author{
Awaludin Rakhmat*, Juandi M., Usman Malik \\ Program Studi S1 Fisika FMIPA, Universitas Riau \\ *E-mail korespondensi: awaludin.rahmat@gmail.com
}

\begin{abstract}
The purpose of the research on the potential of underground water in ring wells in the District of Tenayan Raya Pekanbaru City using the experimental method of pumping test is to determine the potential of underground water, and determine the value of transmissivity so that it can be known the feasibility of well water for surrounding communities. Data was taken on 30 ring wells in Tenayan Raya District, Pekanbaru City. The results obtained are wells that have the lowest potential for underground water in Kadiran Street, Kulim Village with a value of drawdown is $2.1610 \mathrm{~m}$. Wherea the highest potential as good underground water is in the well at Gunung Kidul Street, Tangkerang Timur Village with value of drawdown is $2.0407 \mathrm{~m}$. This ring well has the potential of underground water which is likely to provide water for a long time. The transmissivity obtained from the 30 ring wells is $10.7684 \mathrm{~m}^{2} /$ day. This value shows good groundwater quality and has the potential to meet the needs of residential areas.
\end{abstract}

Keywords: groundwater, pumping test, draw down, transmissivity.

\begin{abstract}
ABSTRAK
Tujuan penelitian tentang potensi air bawah tanah pada sumur cincin di Kecamatan Tenayan Raya Kota Pekanbaru menggunakan metode eksperimen pumping test adalah untuk mengetahui potensi air bawah tanah,dan menentukan nilai transmisivitas sehingga dapat diketahui kelayakan air sumur untuk masyarakat sekitar. Data diambil pada 30 sumur cincin di Kecamatan Tenayan Raya Kota Pekanbaru.Hasil yang diperoleh adalah titik sumur yang memiliki potensi air bawah tanah terjelek berada di Jalan Kadiran Kelurahan Kulim dengan nilai penurunan muka air sebesar 2,1610 m. Sedangkan yang memiliki potensi tertinggi sebagai air bawah tanah yang baik adalah pada sumur di Jalan Gunung Kidul Kelurahan Tangkerang Timur dengan nilai penurunan muka air sebesar 2,0407 m. Sumur cincin ini memiliki potensi air bawah tanah yang berkemungkinan untuk menyediakan air dalam jangka waktu yang lama. Nilai transmisivitas yang di dapat dari ke 30 sumur cincin adalah 10,7684 $\mathrm{m}^{2} /$ hari. Nilai ini menunjukkan kualitas air tanah yang baik dan memiliki potensi untuk memenuhi kebutuhan penduduk.
\end{abstract}

Kata kunci: air tanah, uji pemompaan, penurunan muka air, transmisivitas.

\section{PENDAHULUAN}

Air tanah adalah air yang terdapat dalam lapisan tanah atau batuan di bawah permukaan tanah. Air tanah termasuk segala bentuk aliran hujan yang mengalir dibawah permukaan tanah sebagai akibat struktur perlapisan geologi, beda potensial kelembaban tanah dan gaya gravitasi bumi [1].
Keseimbangan atau kelestarian air tanah akan tercapai apabila input air tanah sama dengan output air tanah atau dengan kata lain volume pengambilan air tanah sama dengan volume penambahan debit air tanah [2]. Pengambilan air tanah yang berlebihan dapat mengakibatkan terjadinya penurunan muka air tanah. 
Keberlanjutan air bawah tanah sangat dipengaruhi oleh berbagai faktor lingkungan [3].

Air tanah yang paling banyak di gunakan adalah air tanah yang terdapat di sumur seperti sumur cincin. Sumur cincin biasa digunakan dalam kehidupan sehari-hari. Air sumur ini digunakan masyarakat dengan cara dilakukan pemompaan atau penimbaan menggunakan ember [4].

Air tanah pada sumur cincin bisa di cari transmisivitasnya yang digunakan untuk mengetahui kemampuan suatu akuifer untuk membawa air tanah yang tertampung dalam satuan luas akuifer perdetiknya. Akuifer yang memiliki nilai transmisivitas yang tinggi menggambarkan potensi air tanah yang lebih baik untuk dimanfaatkan masyarakat.

Penyelidikan kualitas air perlu dilakukan guna menyeimbangkan aspek antara ketersediaannya dengan kebutusa diketahui ada atau tidaknya lapisan pembawa air (akuifer), ketebalan dan kedalamannya serta untuk mengambil Beberapa metode pengujian potensi air bawah tanah pada sumur yang dapat dilakukan, salah satunya yaitu dengan menggunakan metode pumping test. Metode pumping test merupakan metode memompa air dari suatu sumut dengan debit tertentu, mengamati penurunan muka air selama pemompaan berlangsung dan mengamati pemulihan kembali muka air setelah pompa dimatikan sesuai dengan selang waktu tertentu. Pengukuran debit diperiksa setiap kali untuk penurunan muka air dan dicatat dengan benar [5].

Metode pumping test ini dilakukan untuk mengetahui karakteristik akuifer berupa nilai transmisivitas [6]. Metode pumping est merupakan salah satu metode yang digunakan untuk mengetahui transmisivitas suatu umur air tanah. Metode ini dapat digunakan dengan asumsi, yaitu akuifer dipompa dengan debit konstan [7]. Metode Pumping Test digunakan dalam pencarian nilai transmisivitas adalah sebagai berikut:

$$
\mathrm{T}=\frac{2.3 k\left(\frac{\Gamma_{n-}}{\Gamma_{n-l}}\right)}{4 \pi\left(A_{n}-A_{n-l}\right)}
$$

Penelitian ini bertujuan untuk mengetahui potensi air bawah tanah dengan metode pumping test, menentukan nilai transmisivitas air bawah tanah pada sumur cincin dengan metode Pumping Test dan pemetaan kontur potensi air bawah tanah pada 30 titik di KecamatanTenayan Raya Kota Pekanbaru.

\section{METODE PENELITIAN}

Penelitian ini menggunakan metode pumping test dalam melakukan eksperimen dan didapat data sekunder dan data lapangan. Sedangkan analisis karakteristikpotensi air bawah tanahnya menggunakan program Surfer 11d an dilakukan di Laboratorium Fisika Bumi FMIPA UR.

\section{HASIL DAN PEMBAHASAN}

Gambar 1 menampilkan grafik hubungan drawdown (penurunan muka air) s per kapasitas debit air Q terhadap kapasitas debit air Q selama 1 menit di 30 titik di Kecamatan Tenayan Raya Kota Pekanbaru. Hubungan drawdown S per kapasitas debit air Q berbanding lurus terhadap kapasitas debit air $\mathrm{Q}$ selama $\mathrm{t}$ menit. Menunjukkan kenaikan di setiap menit dimana semakin lama uji pemompaan dilakukan maka akan semakin besar nilai drawdown $\mathrm{S}$ dan nilai S/Q. Sumur cincin yang memiliki penurunan muka air terbanyak adalah sumur cincin 30 yang terdapat di Jalan Kadiran di Kelurahan Kulim dengan nilai drawdown sumur rata - rata adalah 2,1610 m. drawdown yang besar menunjukkan potensi air tanah pada Jalan.

Data yang di dapat dari metode pumping test dapat digunakan untuk mencari nilai transmisivitas dengan menggunakan Persamaan (1) sehingga nilai transmisivitas yang didapat pada 30 sumur cincin di Kecamatan Tenayan Raya Kota Pekanbaru adalah10.7684 
$\mathrm{m}^{2} /$ hari.Nilai tersebut mengindikasikan bahwa sumur tersebut memiliki kualitas yang baik dan memiliki potensi untuk memenuhi kebutuhan di pemukiman penduduk.

Gambar 1 merupakan peta kontur yang telah diolah menggunakan program Surfer 11 dengan data $\mathrm{X}$ dan $\mathrm{Y}$ adalah dari koordinat dan $\mathrm{Z}$ dari nilai S/Q. Gambar 2 menunjukkan bahwa Peta kontur yang berada pada warna merah menunjukkan area nilai s/Q tertinggi. Hasil data dari 30 (tiga puluh) sumur cincin pada pemompaan menunjukkan nilai s/Q tertinggi berada pada sumur cincin ke-30 di Jalan Kadiran Kelurahan Kulim yaitu 0,4603 hari $/ \mathrm{m}^{2}$.

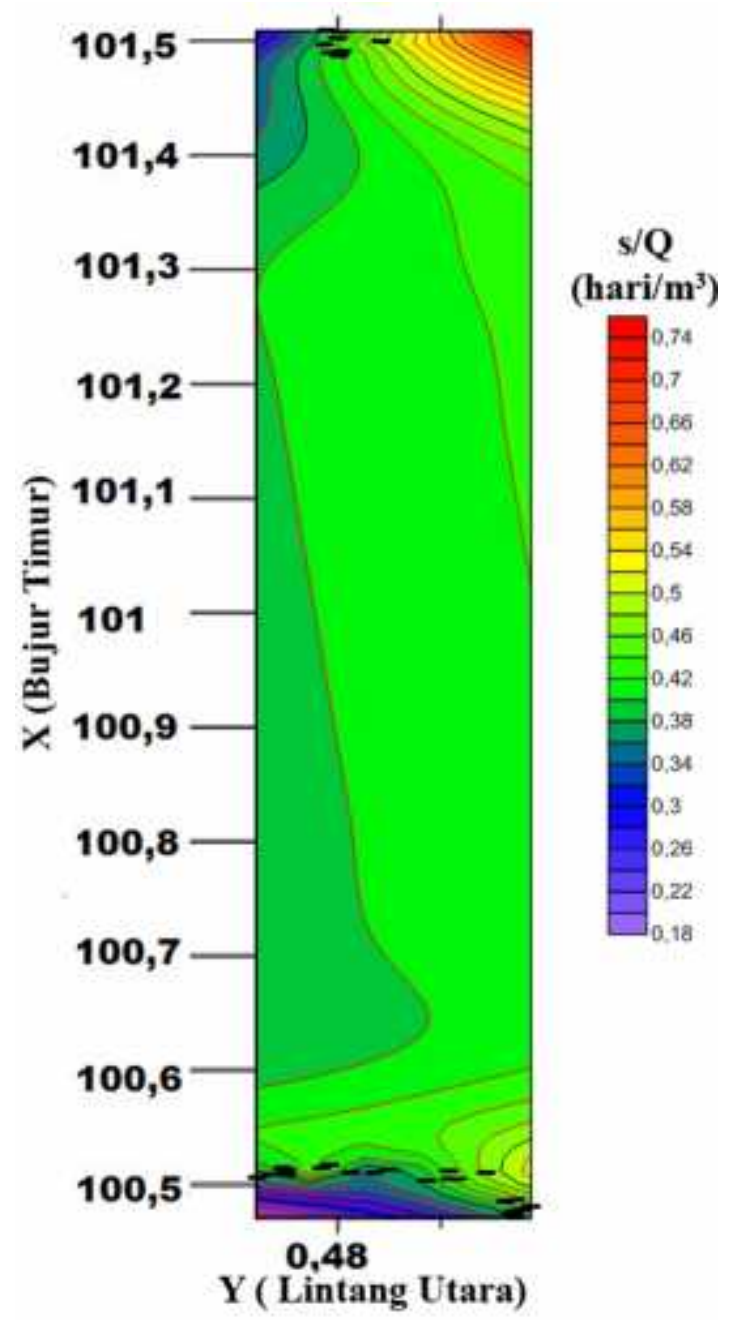

Gambar 1. Peta kontur potensi air tanah S/Q

Daerah ini terletak pada warna biru keunguan, warna tersebut menunjukkan tingginya potensi air bawah tanah diantara 30 titik di Kecamatan Tenayan Raya Kota Pekanbaru.Nilai s/Qterendah berada pada sumur cincin ke-1 di Jalan Jalan Gunung KidulKelurahan Tangkerang Timur yaitu 0,3523 hari $/ \mathrm{m}^{2}$. Area ini terletak pada warna biru menunjukkan rendahnya potensi air bawah tanah diantara 30 titik di Kecamatan Tenayan Raya Kota Pekanbaru.

\section{KESIMPULAN}

Berdasarkan hasil penelitian yang ditelah dilakukan maka dapat diambil kesimpulan sebagai berikut :

1. Potensi air bawah tanah pada Kecamatan Tenayan Raya yang terbaik adalah terdapat pada Jalan Gunung Kidul Kelurahan Tangkerang Timur dengan nilai penurunan muka air sebesar 2,0407 $\mathrm{m}$. Sumur cincin ini memiliki potensi air bawah tanah yang berkemungkinan untuk menyediakan air dalam jangka waktu yang lama. Sedangkan yang terjelek berada pada Jalan Kadiran Kelurahan Kulim dengan nilai penurunan muka air sebesar 2,1610 m.

2. Peta kontur yang berada pada hijau muda menunjukkan area nilai s/Q tertinggi berada pada sumur cincin ke-30 Jalan Kadiran Kelurahan Kulim yaitu 0,4603 hari $/ \mathrm{m}^{2}$. Daerah kontur yang berada pada warna biru menunjukkan daerah nilai s/Qyang terendah berada pada sumur cincin ke-1 Gunung Kidul Kelurahan Tangkerang Timur yaitu 0,3523 hari $/ \mathrm{m}^{2}$, menunjukkan rendahnya potensi air bawah tanah.

\section{DAFTAR PUSTAKA}

1. Asdak, C. (2002). Hidrologi dan Pengelolaan Daerah Aliran Sungai. Gajah Mada University Press, Yogyakarta. 
2. Kodoatie, R. J. (2012). Tata Ruang Air Tanah. Penerbit Andi Offset, Yogyakarta.

3. Juandi, M. (2017). Sustainability Model for Unconfined Aquifers. International Journal of Science and Applied Technology, 1(1), 814.

4. Cikun. (2016). Kualitas Air Tanah di Area Peternakan Sapi Desa Limpakuwus Kecamatan Sumbang Kabupaten Banyumas. Skripsi, Purwokerto: UMP.

5. Elhag, A. B. (2015). New Inovation Method for Analyzing Aquifer Test Data of Pumping and Recovery Test. Int. Res. J Geol, 5.

6. Bisri, M. (2012). Studi Tentang Pendugaan Air Tanah Sumur Air Tandah dan Upayaa dalam Konservasi Air Tanah. UB Press, Malang.

7. Kruseman, G. P., de Ridder, N. A., \& with assistance frome Verweij, J. M. (1970). Analysis and Evaluation of Pumping Test Data. Int. Intitute for Land Recl. and Improvement, The Netherlands. 